JOAL, (JOURNAL, OF APPIIED IINGUIS'IICS AND II'IBRA'TURE)

Vol. 5 No. 1, 2020

ISSN (print): 2502-7816; ISSN (online): 2503-524X

Available online at https:/ / ejournal.unib.ac.id/index.php/joall/index

doi: http:// dx.doi.org/10.33369/joall.v5i1.9739

\title{
LANGUAGE LEARNING STRATEGIES EMPLOYED BY EFL LEARNERS IN A RURAL AREA
}

\author{
Yanik Lailinas Sakinah1; Putu Dian Danayanti Degeng2; Sahiruddin ${ }^{3}$
}

\author{
Universitas Brawijaya ${ }^{1,2,3}$
}

Corresponding email: yaniklailinas@gmail.com

\begin{abstract}
Learning strategy has been widely acknowledged to play an important role in foreign language learning to help the learners in improving language competence. However, studies about language learning in EFL setting in various setting with different participants are still required as to provide a comprehensive representation of how language learning strategies are applied by L2 learners, particularly in an Indonesian EFL setting. This study aimed to examine what language learning strategies are used by EFL learners who work as the local tour guide at National Park of Bromo Tengger Semeru / Taman Nasional Bromo Tengger Semeru (TNBTS), located in East Java, Indonesia. Participants of this study were 33 English learners who work as local tour guide The instruments used was Strategy Inventory for Language Learning (SILL) version 7.0 adapted from Oxford (1990) consisting of 50 questions with 5 scale for each item. This study had a quantitative design as it dealt with the analysis of the numeric data collected from the questionnaire results and employed SPSS software as a tool to analyze descriptive statistics. The result showed that the most frequent strategy used was compensation strategy with mean value 3.64 and the least frequent strategy used was memory strategy with mean value 2.77 .
\end{abstract}

Keywords: Language Learning Strategies, Local Tour Guide, National Park of Bromo

\section{INTRODUCTION}

Rubin (1975) as the pioneer researcher who concerns about the Language Learning Strategy (LLS) suggested examining what strategy successful second or foreign language learners use in detail. Griffiths (2013) defined the LLS is intentional behavior and thoughts used by the learner to help them in understanding, learning, and remembering new information. It is a kind of activity chosen by the learners for specific purposes in regulating their language learning. O'Malley \& Chamot (1990) defined that learning will be 
organized, planned, monitored, and evaluated when the learners use strategies. Accordingly, all the language learners need a good strategy to achieve the goals.

Learning strategy is an individual's approach to an assignment, about how people think and act when they plan, execute, and evaluate the performance on the assignment and its outcomes (Protheroe \& Clarke, 2008). Moreover, foreign language is learned in many fields; formal, non-formal, and in informal setting. The English as Foreign Language (EFL) learners who work as a local tour guide at National Park of Bromo Tengger Semeru /Taman Nasional Bromo Tengger Semeru (TNBTS) have different way in learning a foreign language. They learn English without tutor and they do not join any English course. Inadequate facilities such as internet access, learning media and located in a rural areas become a challenge for them to keep learning. TNBTS is an International tourism attraction and it is located in East Java and one of big tourism attractions in Indonesia. The local tour guide learns EFL to fulfill one of requirements in guiding foreign tourists.

According to researcher's investigation, the local tour guide had been given a guide license card by the provincial government. They had conducted sequence test before guiding tourists. Some who did not pass the test would follow a test in the next session. In this case, the researcher wants to know the preference learning strategies used to develop their English. Gerami \& Baighlou (2011), Su \& Duo (2010), Dawadi (2017), and Ghufron (2017) investigated the LLS used by foreign learners in formal setting. The results showed that the learners used various strategies and implicated that the LLS lead the learners to reach a good achievement in improving language skills. Agreeing this, investigating the EFL learners in different setting to provide the appropriate LLS for improving the target language is required.

Language has a significant role in the communication and understanding between tourists and tourist facilities (Al-saadi, 2016). The role of English as an International language would be a fundamental thing should prepare. President Republic Indonesia has a target to increase Indonesian tourism about 20 million foreign tourists in 2019, in order to fulfill the target of foreign exchange (Nusantara, 2018). For being successful in learning a language, the learners should be aware of learning strategies (O'Malley \& Chamot, 1990). The LLS has a significant part in the learning process of foreign language to assist the learners in improving language competence (Oxford, 1990).

Oxford (1990) defined that there are two common strategies for language learning where both of them are interconnection. Those are Direct and Indirect strategy. Direct language is like the actor on the stage; play with the language itself in some of specific tasks and situations while indirect 
strategy is like the management of learning in general. From those two classes common strategy, Oxford (1990) divide them into six groups strategies. Memory strategy, cognitive strategy, and compensation strategy are under the direct class. For indirect class there are metacognitive strategy, affective strategy and social strategy. From all strategies, Oxford (1990) developed the Strategy Inventory of Language learning (SILL) questionnaire to know which strategy used by the learners in learning a language.

Bobanovic \& Randic (2008), Lai (2009), Salahshour \& Sharifi (2013), Chang \& Liu (2013), Wilujeng (2015), Jiang \& Wu, (2016), (Stracke \& Anam, 2016), (Hadi, 2017), and Shyr et al (2017) have scrutinized the LLS used by EFL learners which aim for knowing the specific LLS used in improving the target language. These studies used SILL questionnaire adopted from Oxford (1990) to identify the most frequent strategy used. Most of these studies were focused on language learning strategies in formal education in case of education needs and mostly they were students from urban areas. While nowadays, foreign language is needed in many fields, instance tourism field to (Reddy, 2016). Furthermore, Widiyati (2017) and Wongthon (2007) scrutinized the EFL learners in tourism fields, however they have analyzed the need of prospective tour guide in acquiring English to speak with foreign tourist without knowing the most LLS used by the learners. Whereas, the appropriate LLS is needed to be analyzed to assist the learners for attaining the target language. Therefore, this study would investigate the LLS used by EFL learners from a rural area at TNBTS to provide the LLS's variation as facilitation on their learning.

\section{METHODS}

\section{Research Design}

In this study, the researcher used quantitative design, deal with questionnaire and the data would be analyzed based on descriptive statistics. In quantitative research the result is expressed in statistical terminology because the data are analyzed mathematically (Latif, 2015).

\section{Participants}

There were 33 participants as the sample who participated in this study. They are local tour guides at TNBTS who guide foreign tourists and have already gotten an officially tour guide license card from East Java Provincial government. The participants were chosen randomly based on the official tour guides lists that are active as a tour guide and willing to be participant.

\section{Instrument and Data Collection}

This study used Strategy Inventory of Language Learning (SILL) instrument version 7.0 developed by Oxford (1990). There were 50 questions containing 
5 points rating scale to value the frequency of the learners' strategy use. The questionnaire SILL was administered to know the frequently strategy used by the learners. The distribution strategy items in SILL by Oxford (1990) can be seen in the table below.

Table: 2 SILL's distribution questions

\begin{tabular}{llll}
\hline & Strategy & Items & Question Number \\
\hline A & Memory Strategy & 9 items & $1,2,3,4,5,6,7,8$, and 9 \\
\hline B & Cognitive Strategy & 14 items & $\begin{array}{l}10,11,12,13,14,15, \\
16,17,18,19,20,21,22 \\
\end{array}$ \\
& & & And 23 \\
\hline C & Compensation & 6 items & $24,25,26,27,28$, and \\
& Strategy & & 29 \\
\hline D & Metacognitive & 9 items & $30,31,32,33,34,35,36$, \\
& Strategy & & 37, and 38 \\
\hline E & Affective Strategy & 6 items & $39,40,41,42,43$, and \\
& & & 44 \\
\hline F & Social Strategy & 6 items & $45,46,47,48,49$, and \\
& & & 50 \\
\hline
\end{tabular}

The participants graded the questionnaire based on the scale items from 1 to 5 where:

1 means never true of me.

2 means rarely true of me.

3 means sometimes true of me.

4 means usually true of me.

5 means always true of me.

\section{Data Analysis}

While in analyzing the data, the researcher used Statistical for the Social Sciences (SPSS) software. The result of this study would be analyzed by using Oxford classification strategy and defined them into three level of frequency.

Table: 3 Classification of Frequency of Use

\begin{tabular}{ccc}
\hline Classification & Frequency of Use & $\begin{array}{c}\text { Average } \\
\text { Score }\end{array}$ \\
\hline \multirow{2}{*}{ Low } & $\begin{array}{c}\text { Never or almost never } \\
\text { used }\end{array}$ & 1.0 to 1.4 \\
\cline { 2 - 3 } & Generally not used & 1.5 to 2.4 \\
\hline Medium & Sometimes used & 2.5 to 3.4 \\
\hline \multirow{2}{*}{ High } & Usually used & 3.5 to 4.4 \\
\cline { 2 - 3 } & Always or almost always & 4.5 to 5.0 \\
\hline
\end{tabular}




\begin{tabular}{ccc}
\hline Classification & Frequency of Use & $\begin{array}{c}\text { Average } \\
\text { Score }\end{array}$ \\
\hline true of me & \\
\hline & Adopted from Oxford (1990)
\end{tabular}

\section{FINDINGS}

The instrument used to elicit Indonesian tour guide's language learning strategies at TNBTS was Strategy Inventory Language Learning (SILL) developed by Oxford (1990). The Cronbach's Alpha showed 0.945 demonstrating that this instrument showed very strong reliability. The normal distribution of the data was assessed through the value of skewness $(S=1.33)$ and kurtosis $(K=-.01)$ demonstrating that the data was normally distributed since the values were not greater than 1.96 or 2.58 (Field, 2009). (Field, 2009).

Based on the research data obtained, the researcher calculated the mean score for six English learning strategy used. The overall mean of each strategy score for all learners was shown in the table below.

Table: 4 The overall mean of each strategy

\begin{tabular}{cccccc}
\hline & $\begin{array}{c}\text { Minimu } \\
\mathrm{m}\end{array}$ & $\begin{array}{c}\text { Maximu } \\
\mathrm{m}\end{array}$ & $\begin{array}{c}\text { Mea } \\
\mathrm{n}\end{array}$ & $\begin{array}{c}\text { Std. } \\
\text { Deviatio } \\
\mathrm{n}\end{array}$ & $\begin{array}{c}\text { Ran } \\
\mathrm{k}\end{array}$ \\
\hline $\begin{array}{c}\text { Compensatio } \\
\mathrm{n}\end{array}$ & 2.67 & 5.00 & 3.64 & 0.58 & 1 \\
\hline Metacognitive & 1.67 & 4.78 & 3.40 & 0.63 & 2 \\
\hline Social & 2.00 & 4.83 & 3.17 & 0.70 & 3 \\
\hline Affective & 2.00 & 4.83 & 3.12 & 0.57 & 4 \\
\hline Cognitive & 1.79 & 4.43 & 2.83 & 0.60 & 5 \\
\hline Memory & 2.00 & 4.56 & 2.77 & 0.53 & 6 \\
\hline
\end{tabular}

It can be seen from the table above, the strategies that most frequently used by the local tour guide at TNBTS was compensation strategy with mean score 3.64. After compensation strategy there was metacognitive strategy as the second strategy frequently used by a mean score 3,4. Moreover, for the other strategies, such as memory, cognitive, affective, and social strategy were also used but they have a low mean score compared to the compensation and metacognitive strategy with $2.77,2.83,3.12$, and 3.17 respectively. While the least frequently used was memory strategy, because the mean was about 2.77 only.

There were six questions should be answered to represent the compensation strategy in the SILL. The percentage in each question was explained by using charts below. 


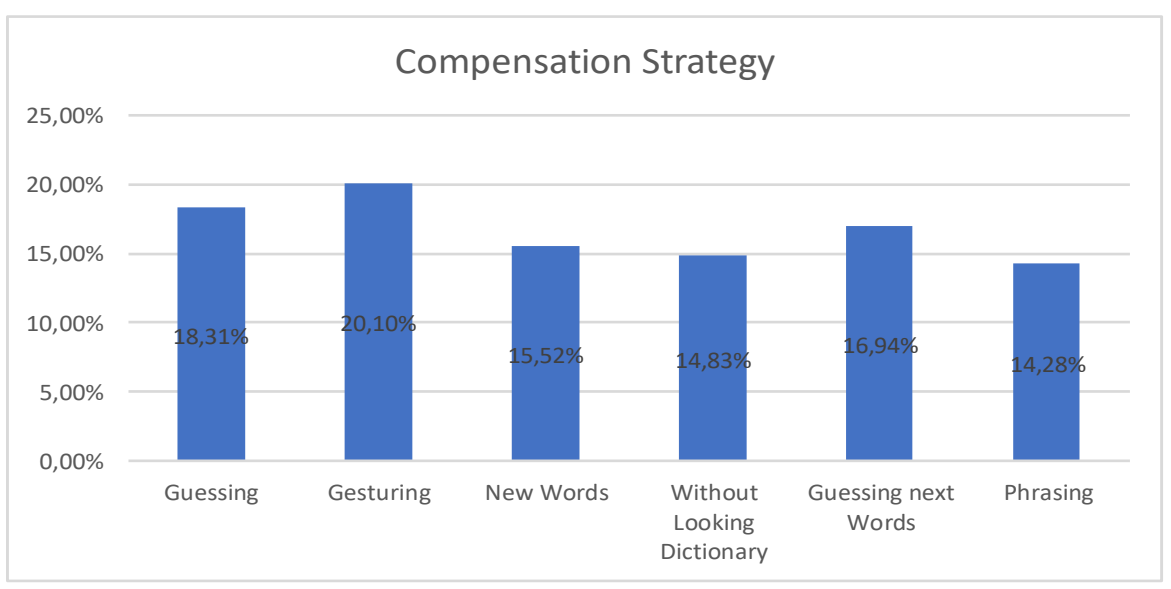

Most learners use a gesture or body language when they do not understand something in English during communication. It was about $13,30 \%$ of all participants claiming this way as a strategy. Guessing was also the strategy under compensation strategy receiving $12,12 \%$ response of use by the learner when they did not understand about something in English. Thus, gesturing and guessing were the best way for some learners when they felt difficult in learning English. This strategy brought an advantage to solve the lack of knowledge of the target language.

The overall mean score from all learners was 3.1. It showed that the level of frequency for the learners were medium level. It means that almost all learners answered "sometimes true of $m e$ " on the questionnaire. The descriptive statistics of the language learning strategy used from SILL would be displayed in the table below.

Table: 5 The descriptive statistics of the language learning strategy

\begin{tabular}{llcc}
\hline \multirow{2}{*}{ Item } & \multicolumn{1}{c}{ Strategy } & Mean & Mo \\
\cline { 2 - 4 } 1 & $\begin{array}{l}\text { think of relationships between what } \\
\text { already know and new things that } \\
\text { learned in English. }\end{array}$ & 3.45 & 3 \\
\hline 2 & $\begin{array}{l}\text { practice new English words in a } \\
\text { sentence so can remember them. }\end{array}$ & 3.09 & 2 \\
\hline 3 & $\begin{array}{l}\text { connect the sound of a new English } \\
\text { word and an image or picture of the } \\
\text { word to assist in remembering the } \\
\text { word. }\end{array}$ & & \\
\hline 4 & $\begin{array}{l}\text { remember a new English word by } \\
\text { creating a mental picture of a } \\
\text { situation in which the word might be } \\
\text { used. }\end{array}$ & & 4 \\
\hline
\end{tabular}




\begin{tabular}{|c|c|c|c|}
\hline \multirow{2}{*}{ Item } & \multirow{2}{*}{ Strategy } & \multicolumn{2}{|c|}{ Learners } \\
\hline & & Mean & Mo \\
\hline 5 & $\begin{array}{l}\text { use rhymes to memorize new } \\
\text { English words }\end{array}$ & 1.90 & 2 \\
\hline 6 & $\begin{array}{l}\text { use flashcards to remember new English } \\
\text { words. }\end{array}$ & 1.54 & 1 \\
\hline 7 & physically act out new English words. & 3 & 3 \\
\hline 8 & review English lessons often. & 2.81 & 2 \\
\hline 9 & $\begin{array}{l}\text { remember new English words or } \\
\text { phrases by remembering the location on } \\
\text { the page, on the board, or on a street } \\
\text { sign. }\end{array}$ & 2.69 & 3 \\
\hline 10 & $\begin{array}{l}\text { say or write new English words several } \\
\text { times }\end{array}$ & 2.57 & 2 \\
\hline 11 & try to talk like a native speaker & 3.81 & 4 \\
\hline 12 & practicing the sounds of English & 3.42 & 3 \\
\hline 13 & $\begin{array}{l}\text { use the English words that know in } \\
\text { different ways }\end{array}$ & 2.54 & 2 \\
\hline 14 & start conversation in English & 2.81 & 3 \\
\hline 15 & $\begin{array}{l}\text { watch English language TV shows } \\
\text { spoken in English or go to movies } \\
\text { spoken in English }\end{array}$ & 3.54 & 4 \\
\hline 16 & read for pleasure in English. & 2.24 & 2 \\
\hline 17 & $\begin{array}{l}\text { write notes, messages, letters, or } \\
\text { reports in English. }\end{array}$ & 1.96 & 1 \\
\hline 18 & $\begin{array}{l}\text { first skim an English passage (read } \\
\text { over the passage quickly) then go } \\
\text { back and read carefully }\end{array}$ & 2.51 & 2 \\
\hline 19 & $\begin{array}{l}\text { look for words in first language that } \\
\text { are similar to new words in English. }\end{array}$ & 2.54 & 2 \\
\hline 20 & try to find the patterns in English. & 2.87 & 3 \\
\hline 21 & $\begin{array}{l}\text { find the meaning of an English word by } \\
\text { dividing it into parts that can be } \\
\text { understand }\end{array}$ & 3.30 & 3 \\
\hline 22 & try not to translate word-for-word. & 3.21 & 3 \\
\hline
\end{tabular}




\begin{tabular}{|c|c|c|c|}
\hline \multirow{2}{*}{ Item } & \multirow{2}{*}{ Strategy } & \multicolumn{2}{|c|}{ Learners } \\
\hline & & Mean & Mo \\
\hline 23 & $\begin{array}{l}\text { make summaries of information that } \\
\text { already heard or read in English. }\end{array}$ & 2.36 & 2 \\
\hline 24 & $\begin{array}{l}\text { understanding unfamiliar English } \\
\text { words, make guesses }\end{array}$ & 4 & 4 \\
\hline 25 & $\begin{array}{l}\text { When can't think of a word during a } \\
\text { conversation in English, using } \\
\text { gestures }\end{array}$ & 4.39 & 5 \\
\hline 26 & $\begin{array}{l}\text { make up new words if do not know the } \\
\text { correct ones in English. }\end{array}$ & 3.39 & 3 \\
\hline 27 & $\begin{array}{l}\text { read English without looking up } \\
\text { every new word }\end{array}$ & 3.24 & 3 \\
\hline 28 & $\begin{array}{l}\text { try to guess what the other person } \\
\text { will say next in English }\end{array}$ & 3.69 & 3 \\
\hline 29 & $\begin{array}{l}\text { If can't think of an English word, } \\
\text { using a word or phrase that means } \\
\text { the same thing }\end{array}$ & 3.12 & 3 \\
\hline 30 & $\begin{array}{l}\text { try to find as many ways as can to use } \\
\text { my English. }\end{array}$ & 3.42 & 3 \\
\hline 31 & $\begin{array}{l}\text { notice my English mistakes and use } \\
\text { that information to help me do } \\
\text { better. }\end{array}$ & 3.78 & 4 \\
\hline 32 & $\begin{array}{l}\text { pay attention when someone is } \\
\text { speaking English. }\end{array}$ & 4.09 & 4 \\
\hline 33 & $\begin{array}{l}\text { try to find out how to be a learner of } \\
\text { English. }\end{array}$ & 2.96 & 3 \\
\hline 34 & $\begin{array}{l}\text { plan my schedule, then will have } \\
\text { enough time to study English }\end{array}$ & 2.66 & 3 \\
\hline 35 & $\begin{array}{l}\text { look for people who can talk to in } \\
\text { English. }\end{array}$ & 3.57 & 4 \\
\hline 36 & $\begin{array}{l}\text { look for opportunities to read as much } \\
\text { as possible in English. }\end{array}$ & 2.75 & 2 \\
\hline 37 & $\begin{array}{l}\text { have clear goals in improving the } \\
\text { English skills }\end{array}$ & 3.93 & 4 \\
\hline 38 & $\begin{array}{l}\text { think about the progress in learning } \\
\text { English }\end{array}$ & 3.39 & 3 \\
\hline 39 & $\begin{array}{l}\text { trying to relax whenever feel afraid of } \\
\text { using English }\end{array}$ & 4 & 4 \\
\hline 40 & $\begin{array}{l}\text { encourage self to speak English even } \\
\text { when afraid of making a mistake. }\end{array}$ & 4.12 & 5 \\
\hline
\end{tabular}




\begin{tabular}{|c|c|c|c|}
\hline \multirow{2}{*}{ Item } & \multirow{2}{*}{ Strategy } & \multicolumn{2}{|c|}{ Learners } \\
\hline & & Mean & Mo \\
\hline 41 & $\begin{array}{l}\text { give our self a gift, reward or treat } \\
\text { when do well in English. }\end{array}$ & 3.21 & 4 \\
\hline 42 & $\begin{array}{l}\text { notice if be anxious or nervous when } \\
\text { studying or using English. }\end{array}$ & 3.36 & 3 \\
\hline 43 & $\begin{array}{l}\text { write down the feelings in a } \\
\text { language learning diary }\end{array}$ & 1.66 & 1 \\
\hline 44 & $\begin{array}{l}\text { talk to someone else about how it } \\
\text { feel when learning English }\end{array}$ & 2.39 & 2 \\
\hline 45 & $\begin{array}{l}\text { If do not understand something in } \\
\text { English, then ask the other person to } \\
\text { slow down or say it again }\end{array}$ & 4.24 & 4 \\
\hline 46 & ask speakers to correct when talk & 3.33 & 3 \\
\hline 47 & practice English with other learners & 2.33 & 2 \\
\hline 48 & ask for help from English speakers & 3 & 3 \\
\hline 49 & ask questions in English & 3.24 & 3 \\
\hline 50 & $\begin{array}{l}\text { try to learn about the culture of } \\
\text { English speakers }\end{array}$ & 2.90 & 3 \\
\hline
\end{tabular}

From the table above, based on the analysis of the frequently strategy used, gesturing strategy was the most frequently used. The mode in the item number 25 was 5 . It means that, the most learners answered "always true of $m e^{\prime \prime}$ that was the highest grade in the SILL questionnaire. Gesturing strategy includes in compensation strategy from one of strategies in direct class strategy, the classification from Oxford (1990). Gesture or mime would be used by the learners at TNBTS when they felt difficult in understanding something new in their target language when doing communication. The mean score was about 4.39, it showed that the learners were in the high level used, especially in gesturing strategy. In conclusion, 55,3\% of all strategies in 33 participants used compensation strategy as the frequently used for acquiring the language.

\section{DISCUSSION}

Compensation strategy is the direct strategy used to conquer knowledge limitations in four skills for learning and producing the target language (Oxford, 1990). This strategy can be used for all language learners to help them in acquiring a language. Several EFL learners from different settings used this strategy as the most frequent strategy such as; Chang \& Liu (2013), Wilujeng (2015) and Jiang \& Wu, (2016). Most of the participants had mid to 
high level English proficiency EFL learners. Moreover, these results were in contrast to Oxford (1990) which asserted that the compensation strategy is suggested for the beginner and intermediate language learners.

In this paradigm, compensation strategy has a significant role to help the learners who are lack of knowledge concerning the target language both theoretically and practically. This could be reinforced by what Oxford (1990) has asserted. Yet, it is also useful for advance learners who occasionally do not understand an expression in the target language. Therefore, compensation strategy is convenient to the all level of English proficiency.

Furthermore, those previous studies in line with the current study's result where the compensation strategy become the most commonly used to assist the learners when they get difficulties in understanding or practicing the target language. Indeed, the learners' setting could influence the learners to choose the specific strategy. However, the current study showed the LLS used by EFL learners from a rural area and would give implication for English language learners in Indonesia. It can be seen from the result that using gestures and guessing words became the most frequently strategies used. The learners were also encouraging their self to speak English even when anxious of making a mistake. This can be interpreted that their language skills still need to be developed by using or adding new strategies to achieve the best results by mastering as both theoretical and practical. Besides, it also gave an implication that the learners would be more active and self-regulated because they have limited classroom contact hours with the English tutor except of limited access and facilities to support their learning.

The more proficient learners used more language learning strategies (Oxford,1990). Lai (2009) and Bobanovic \& Randic (2008) scrutinized that the LLS used EFL learners who had high level proficiency would use more strategies. They used meta- cognitive strategies and cognitive strategies for the highest frequently used. It was also showed that compensation strategy gets a lower frequency comparing with metacognitive and cognitive strategy. This proves that compensation strategy is mostly used for the language learners who has lack of knowledge and do not mastering the theories as well. Therefore, guessing, gesturing or body language, and mime would help them to overcome the problems.

In addition, it was similar to a study which is conducted by Chang \& Liu (2013) that the compensation strategy was also employed by the learners among EFL university freshmen. This strategy was mostly used by the learners who has low level English proficiency. In this study, the researcher also compared with the learner's motivation. It has a highly significant from the frequency of strategy use and had positive correlation with their motivation. In compensation strategy the learners enable to use the target 
language for comprehension or production whereas has limitation in knowledge. In this case, when the learners do not know the grammar or loss the vocabulary the different way may be used to deliver the message. However, the current study shows that the learners must use various language learning strategies, not only applying the compensation strategy but also the other strategies. It also gives a recommendation for the government to give sustainable English training to the EFL learners who work as a local tour guide, due to increase their skills for guiding tourists.

Through this study, the provincial government can have empirical data to conduct training for those who have been selected as tour guide and for those who have not. Because the findings reveal that the EFL learners at TNBTS need to improve their learning strategies to achieve the target language expertly. Therefore, the quality of the guide will be much better and have a good impact for Indonesian tourism.

\section{CONCLUSION AND SUGGESTION}

Based on the result of the SILL questionnaire analysis, the local tour guide at TNBTS implemented compensation strategy to achieve the goal of learning. In overall result gesturing and mime strategies in compensation was the highest frequently used. Almost all of learners used this way to avoid misunderstanding and to overcome the problems if they faced some difficulties in the target language. It was implicated that the tour guides do not have much theoretical knowledge towards the target language. Therefore, the learners tend to use guessing and body language for solving the problems while acquiring the target language. To conclude, there should be a training, workshop or kind of English short course for the local tour guide at TNBTS to improve the strategies used and mastering the target language.

At last, the researcher give suggestion to the provincial government for not only ask them to get official license of tour guiding but also give sufficient input knowledge to get the best result in guiding foreign tourist by mastering the language both theoretically and practically from training education and short course. In addition, the LLS used by foreign tour guide may need to be conducted in wide and more samples to make the English learning strategies more variable.

\section{REFERENCES}

Al-saadi, N. (2016). Importance of English Language in the Development of Tourism. Academic Journal of Accounting and Economics Researches, 4(1), 33-45.

Bobanovic, M. K., \& Randic, N. A. (2008). Language Learning trategies In Different English As A Foreign Langauge Education. Language Learning, 
17(93-94), 281-300.

Chang, C., \& Liu, H.-J. (2013). Language Learning Strategy Use and Language Learning Motivation of Taiwanese EFL University Students. Electronic Journal of Foreign Language Teaching, 10(2), 196-209.

Dawadi, S. (2017). Language Learning Strategies Profiles of EFL Learners in Nepal. European Journal of Educational \& Social Sciences, 2(2), 42-55.

Field, A. (2009). Discovering statistics Using SPSS (Third Edit). London and New York: Sage.

Gerami, M. H., \& Baighlou, S. M. G. (2011). Language Learning Strategies Used by Successful and Unsuccessful Iranian EFL Students. ElsevierProcedia - Social and Behavioral Sciences, 29, 1567-1576. https:/ / doi.org/10.1016/j.sbspro.2011.11.399

Ghufron, M. A. (2017). Language Learning Strategies Used by EFL Fluent Speakers: A Case in Indoendian Context, 6(2), 184-202. https://doi.org/10.15642/ijet.2017.6.2.184-202

Griffiths, C. (2013). The strategy Factor in Successful Language Learning, 3, 103.

Hadi, F. N. (2017). Language Learning Strategies Used By Thai Students in Learning English and Indonesian. Lampung University.

Jiang, W., \& Wu, Q. (2016). A Comparative Study on Learning Strategies used by Australian CFL and Chinese EFL learners, 5(2), 213-239. https:/ / doi.org/10.1515/caslar-2016-0009

Lai, Y.-C. (2009). Language Learning Strategy Use and English Proficiency of University Freshmen in Taiwan. Tesol Quarterly, 43(2), 255-280. https://doi.org/https://doi.org/10.1002/j.1545-7249.2009.tb00167.x

Latif, M. A. (2015). Research Method on Language Learning An Introduction (2nd Ed). Malang: Universitas Negeri Malang.

Nusantara, T. (2018). Perkembangan Pariwisata Indonesia. Retrieved from https:/ / www.tagarnusantara.com/

O'Malley, J. M., \& Chamot, A. U. (1990). Learning Strategies in Second Language Acquisition (1st Ed). United States of America: Cambridge University.

Oxford, L. R. (1990). Language Learning Strategy. Newbury House: Oxford University Press.

Protheroe, N., \& Clarke, S. (2008). Learning Strategies as a Key to Student Success, (December), 33-37.

Reddy, M. S. (2016). Importance of English Language in today's World. International Journal of Academic Research, 3(4), 2348-7666. https:// doi.org/10.1016/j.cbi.2008.10.048

Rubin, J. (1975). What the "Good Language Learner " Can Teach Us. Tesol, 9(1), 41-51. Retrieved from http://www.jstor.org/stable/3586011. Accessed: 
Salahshour, F., \& Sharifi, M. (2013). The relationship between language learning strategy use, language proficiency level and learner gender. Social and Behavioral Sciences, 70(1957), 634-643. https://doi.org/10.1016/j.sbspro.2013.01.103

Shyr, W.-J., Feng, H.-Y., Zeng, L.-W., Hsieh, Y.-M., \& Shih, C.-Y. (2017). The Relationship between Language Learning Strategies and Achievement Goal Orientations from Taiwanese Engineering Students in EFL Learning. Journal of Mathematics Science and Technology Education, 8223(1), 6431-6443. https://doi.org/10.12973/ejmste/76660

Stracke, E., \& Anam, S. (2016). Language learning strategies of Indonesian primary school students: In relation to self-ef fi cacy beliefs. Elsevier, 60(0346-251X), 1-10. https://doi.org/10.1016/j.system.2016.05.001

$\mathrm{Su}$, M. M., \& Duo, P. (2010). EFL Learners ' Language Learning Strategy Use as a Predictor for Self-Directed Learning Readiness. The Journal of Asia TEFL, 7(2), 153-176.

Widiyati, E. (2017). Analyzing The Need of Prospective Tour Guides in Acquiring English To Communicate With Foreign Tourists in Desa Menari as Tourism Village. International Langauge Development, 285-293.

Wilujeng, N. C. S. (2015). How do the Darmasiswa students learn Indonesian language in Yogyakarta State University, Indonesia? Journal of Education, 8(1), 10-15. Retrieved from https://journal.uny.ac.id/index.php/joe/article/download/9606/7669

Wongthon, Y. (2007). Learning English outside the classroom : Case study of tuk-tuk drivers in Phranakhon Si Ayutthaya 1. International Education Journal, 8(2), 433-448. https://doi.org/http://iej.com.au 